\title{
THE EFFECT OF COMPANY CHARACTERISTICS TOWARDS CARBON EMISSION DISCLOSURE AND ITS IMPACT ON ECONOMIC CONSEQUENCES IN NON-FINANCIAL REGISTERED COMPANIES IN INDONESIA, MALAYSIA, THAILAND AND THE PHILIPPINES PERIOD FOR 2008-2017
}

\author{
Gatot Nazir Ahmad ${ }^{1}$ \\ ${ }^{1}$ Faculty of Economics, Universitas negeri Jakarta \\ Jakarta, Indonesia \\ ahmad72nazir@gmail.com \\ Roh Ajiasri \\ ${ }^{2}$ Faculty of Economics, Universitas negeri Jakarta \\ Jakarta, Indonesia \\ Caitlyn27062014@gmail.com \\ Ari Warokka ${ }^{3}$ \\ ${ }^{3}$ Faculty of Economics, Universitas negeri Jakarta \\ Jakarta, Indonesia \\ ari.warokka@gmail.com
}

\begin{abstract}
This research was conducted to know the company's characteristics, the determining factors for the disclosure of carbon emissions, and the impact of the disclosure of carbon emissions on economic consequences. The financial result in this study is the decision-making behavior of businesses, governments, and creditors as a result of accounting reporting, in this case, environmental disclosures contained in annual reports and sustainable reports. This study's sample amounted to 45 companies registered in Indonesia, Malaysia, Thailand, and the Philippines, with an observation period of 2008 to 2017. To measure the disclosure of carbon emissions by creating a checklist based on information from the CDP. Company characteristics are proxied by profitability, leverage, size, and sales growth, while economic consequences are proxied by the bid-ask spread, trading volume, and stock price volatility. The analytical method used in this study is the Partial Least Square (PLS) method using the WARP
\end{abstract}


PLS version 5.0 application. From the test results, it was found that Profitability and Size had a positive effect on disclosure of carbon emissions, growth sales had a negative effect, and leverage had no effect. Meanwhile, the impact of disclosing carbon emissions on the bid-ask spread, trading volume, and stock price volatility has a positive effect.

Keywords: disclosure of carbon emissions, company characteristics, economic consequences

\section{INTRODUCTION}

The rapid industrial development and the high growth of the global population with all consumption patterns and people's lifestyles have caused environmental problems. Countries in the Southeast Asian region are reported to be the most significant contributors to carbon emissions globally. According to a report from the National Climate Change Secretariat (2019), it was stated that developing countries in the Southeast Asia region, namely Thailand, Malaysia, Indonesia, and the Philippines, are the countries with the highest carbon emissions, where steps should be taken to reduce emissions. As a follow-up to efforts to reduce carbon emissions, the Government of Indonesia issued Law Number 16 of 2016 concerning the Ratification of the Paris Agreement to The Nations Framework Convention On Climate Change related to climate change caused by the effect of greenhouse gases. Then Thailand also took steps to reduce emissions by carrying out projects related to transportation and climate change which included 2 phases, namely the first phase (2012-2015) and the second phase (2016-2018), supporting the development of Thailand's NDC for the transportation sector (TCC, 2019). Likewise, Malaysia emphasized reducing carbon emissions by 45 percent by 2030 and being completely carbon neutral by 2050 (New Strait Time, 2019). Furthermore, the Philippines' Government stated that in 2010, the Philippine Climate Change Commission (CCC) formulated a National Framework Strategy 2010-2022 on Climate Change that identified long-term mitigation goals to facilitate the transition to low GHG emissions for sustainable development (Climatelink, 2016). From Indonesia to the Philippines have 
taken steps to mitigate carbon emissions and reduce emissions to preserve the environment for future generations. For that, the private sector's participation is urgently needed to participate in collaborating to reduce the company's carbon emissions.

There is already an agency/institution that supports the need for carbon emission disclosure and calculates and reports carbon emissions, namely the Carbon Disclosure Project (CDP). CDP stated that it is crucial to disclose carbon emissions for global business success in the 21 st century. Disclosure of carbon emissions makes a significant contribution to the company, namely improving its reputation, thereby increasing public trust in the company. The disclosure of carbon emissions also affects investment decision criteria, including investors' behavior, public policies that require investors to disclose how they can make environmental considerations without further guidance, and potential markets that provide long-term and short-term perspectives for investors. Several reasons companies need to disclose carbon emissions, namely as an expression of public communication, stakeholder interests (customers, employees, and investors), transparency, the importance of understanding the business, reducing costs, legal requirements, and understanding environmental impacts (Blanco, Caro, \& Corbett, 2017; Knudsen, 2016; Haigh \& Shapiro, 2011). A solid commitment to disclosing reports can reduce the possibility of information asymmetry that arises between the company and its shareholders (Leuz \& Verrecchia, 2000). For this reason, it is necessary to conduct a more in-depth study related to the role of companies in disclosing carbon emissions.

Research on carbon emission disclosure is inseparable because it is influenced by company characteristics. The research on the effect of company characteristics on disclosure of carbon emissions has been carried out, among others, by Choi, Lee, and Psaros (2013) using variables of carbon emission levels, type of industry, size, profitability, leverage, and corporate governance. Ghomi and Leung (2013) using size, company age (age of firm), leverage, listing status, corporate governance, industry type, and ownership. Chithambo and Tauringana (2014) use variable size (size), profitability, liquidity, company age, industry type, leverage, capital expenditure, and financial slack. Abubakar (2017) profitability, size, leverage, and board size. The results of these studies still do not provide the same results, so the authors intend to test companies' characteristics that influence the disclosure of carbon emissions in non-financial 
companies in the regions of Indonesia, Malaysia, Thailand, and the Philippines. As well as conducting research on the impact of disclosing carbon emissions on economic consequences.

\section{LITERATURE REVIEW}

\section{Theoretical Study}

\section{Legitimacy Theory}

Legitimacy is understood as the conformity between institutional action and social values, and a legitimacy is an act of giving signals of value congruence or changing social values in institutions. Every publication made by the company will be vital because it can lead people's perceptions to believe what the company announces (Donaldson \& Preston (1995)). Companies' legitimacy perspective of environmental disclosure as a form of action that is expected by the community and to create a good image in society and the disclosure made is increasing from year to year (Patten, 1992; Deegan \& Rankin, 1997). The company is responsible for managing and evaluating carbon emissions, so that the company needs legitimacy to attract the trust of the community and its stakeholders.

\section{Signaling Theory}

Signal theory assumes that managers have a lot of information that can be used to predict the company's future performance, so company managers are able to predict future performance because they have more information than outsiders. Managers are able to improve company performance through voluntary disclosure and are considered relevant for image building (Healy \& Palepu, 2001). According to Gray, Kouhy, and Lavers (1995), managers have the motivation to voluntarily disclose additional accounting information, such as disclosing the company's environment, which can be used as a signal indicating that the company is concerned about its environment. This activity is carried out to attract investors because it can increase the company's positive reputation and corporate value.

\section{Stakeholder Theory}

Stakeholder theory that company management is expected to carry out activities mandated by stakeholders and report on these activities. Stakeholders have the right to receive information about the impact that will be caused by the activities carried out by the company. Therefore, companies must pay attention to stakeholders because of their 
position as parties that are directly or indirectly influenced by the activities carried out by the company (Guthrie, Petty, Yongvanich, \& Ricceri, 2004).

\section{Carbon Emissions Disclosure}

Carbon emissions result from activities that emit gases such as carbon dioxide and methane into the atmosphere, which can change the environment to become worse due to climate change (PPNS, 2017). There are 7 (seven) industrial sectors that contribute to intensive carbon emissions, namely chemicals and pharmaceuticals; construction and building products; manufacture; oil and gas; raw materials, mining, paper and packaging; transportation and logistics; and utility (Haigh et al., 2011). The increasing industrial activity contributes to carbon emissions which are predicted to continue to increase until 2050, which can cause an increase in temperature on the earth's surface that can endanger life on earth (OECD, 2011; IPCC, 2013 \& 2018; World Economic Forum, 2017). Then the Kyoto protocol was published as a basis for disclosing carbon emissions (Luo et al., 2013). This disclosure is a free choice for company management to provide accounting information and other relevant information (Wulandari \& Atmini, 2012). Disclosure of carbon emissions is a series of quantitative and qualitative information in the past. The company will predict the company's future carbon emissions, further details of the disclosure, and its implications for company finances in facing climate change (Cotter \& Najah, 2011). This disclosure is used to encourage companies to reduce carbon emissions and manage carbon (Saka et al., 2014).

\section{Hypothesis Development}

\section{Effect of Profitability on Carbon Emission Disclosure}

Choi et al. (2013) found that large listed companies in Australia with high profitability levels were able to disclose well-equipped information to act on environmental stressors effectively and were willing to solve problems quickly. Likewise, Jannah and Muid (2014) stated that companies listed on the Indonesia Stock Exchange that have good financial conditions would be more likely to disclose environmental information. Companies with high profitability can better disclose information and simultaneously signal that they can act well against environmental stresses effectively. Iatridis (2013) reveals that companies in Malaysia with a high level of profitability have high disclosure scores and high environmental performance. Likewise with Abubakar (2017). Unlike the 
case with Chithambo et al. (2014), who found negative results. Likewise with research conducted by Irwhantoko et al. (2016); Kusumah et al. (2016); Welbeck et al. (2017); Burgwal et al. (2014) who did not find a relationship of influence. That there are still different results, the authors conducted another study on the effect of profitability on disclosure of carbon emissions.

H1: Profitability has a positive effect on disclosure of carbon emissions

\section{Effect of Leverage on Carbon Emission Disclosure}

Several previous studies related to leverage with disclosure of carbon emissions, namely Iatridis (2013), stated that companies in Malaysia with high leverage, in the sense that they have limited capital, tend to provide informative disclosures that are positively related to funding. The manager's behavior will be monitored intensively by the lender and will be more effective by providing environmental disclosures to open up opportunities for obtaining funds. Likewise Ambarwati and Hapsoro (2017) stated that companies with a higher level of leverage tend to increase the more information available on disclosing carbon emissions. This results from a company trying to maintain or enhance its reputation from the perspective of stakeholders and debt holders in order to maintain the possibility of obtaining a loan. Meanwhile, Chithambo et al. (2014) found significant negative results on disclosure as well as Jannah et al. (2014) and Irwhantoko et al. (2016), who found the same result. Abubakar (2017); Kusumah et al. (2016) did not find a significant effect between leverage and carbon emissions disclosure. That there are still different results, the authors conducted another study on the effect of leverage on disclosure of carbon emissions.

$\mathrm{H} 2$ : Leverage has a positive effect on carbon emission disclosure

\section{The Effect of Size on Carbon Emission Disclosure}

Welbeck et al. (2017) found a positive influence between size and disclosure of carbon emissions in Ghana's listed companies. Larger companies disclose environmental information. In addition, as a form to attract public trust and attract external funding to make environmental disclosure reports. In accordance with the principles of legitimacy theory, companies will be subject to public pressure to disclose information about their environmental activities in order to gain legitimacy. Similarly, Ghomi et al. (2013); Choi et al. (2013), and Prafitri et al. (2016) show that large companies are under high pressure 
from the public and the government so that they tend to pay more attention to environmental aspects, one of which is by disclosing carbon emissions. Large companies will be more open to the public and encourage voluntary reporting because they carry out activities that affect the environment and generate greater scrutiny from the public and government. In addition, large companies generally have a large number of shareholders who may be interested in social change and environmental activities. Different results are shown by Abubakar (2017), Irwhantoko et al. (2016), Kusumah et al. (2016), who did not find a significant effect. That there are still different results, the authors conducted another study on the effect of size on the disclosure of carbon emissions. From the above studies, the hypothesis can be formulated, namely:

H3: Company size has a positive effect on disclosure of carbon emissions

\section{The Effect of Growth Sales on Carbon Emission Disclosure}

Munsaidah et al. (2016) stated that companies with high growth would be in the spotlight of investors because they are considered that with high growth, they will better carry out social and environmental responsibility. Widiastuti, Utami, and Handoko (2018) found negative results. Different results were shown by Effendi et al. (2015), Kansal et al. (2014), Lucyanda et al. (2012), Waluyo (2017), did not find significant results. That there are still different results, the authors conducted another study on the effect of growth sales on the disclosure of carbon emissions. From the above studies, the hypothesis can be formulated, namely:

H4: Sales growth has a positive effect on carbon emission disclosure

\section{The Effect of Carbon Emission Disclosure on the Bid-Ask Spread}

Cho, Lee, and Pfeiffer (2013) stated a significant negative effect on the bid-ask spread. High bid-ask spreads occur because of the cost of information asymmetry. To reduce the cost of asymmetry, which can lead to possible losses, traders increase spreads to minimize losses. Thus, even information is needed by reducing information asymmetry to reduce the spread between the supply and ask prices. Social and environmental disclosures made by companies are able to reduce market uncertainty. The same is the case with Michaels and Gruning (2017); Ambarwati et al. (2017) and Hapsoro and Zidni (2015) found significant negative results on the effect of carbon emission disclosure on its bid-ask spread. The more information is available on disclosure of carbon emissions, the smaller 
the bid-ask spread will be. The information available with a broader range of distribution is one proof of corporate social responsibility so that it impacts the smaller bid-ask spread. Unlike Candra and Juniarti (2017), Hapsoro and Fadhilla (2017) found significant positive results. Whereas there are still different results, the authors conducted another study on the effect of disclosing carbon emissions on the bid-ask spread. From the above studies, the hypothesis can be formulated, namely:

H5: The disclosure of the company's carbon emissions has a negative effect on the bidask spread

\section{The Effect of Carbon Emission Disclosure on Trading Volume}

Hapsoro et al. (2017) found a significant positive result on stock trading volume. This means that public companies' disclosures in Indonesia provide signals that are responded positively by investors in the capital market, thereby increasing the volume of stock trading. In his findings, information on social responsibility disclosure that discusses the environment and human rights can increase stock trading volume in the Indonesian capital market. Likewise, Ambarwati et al. (2017) found a positive effect of disclosing carbon emissions on trading volume. This indicates that the more disclosures available on disclosure of carbon emissions, the higher the investors' interest to invest in the company. Then Zidni (2016) and Hapsoro et al. (2015) also found the same result. Meanwhile, Astuti and Nugrahanti (2015) found no significant results. Whereas there are still different results, the authors conducted another study on the effect of disclosing carbon emissions on trading volume. From the above studies, the hypothesis can be formulated, namely:

H6: The disclosure of the company's carbon emissions has a positive effect on the volume of stock trading

\section{The Effect of Carbon Emission Disclosure on Shares Price Volatility}

Ambarwati et al. (2017) found a negative effect on stock price volatility. This implies that the more disclosures available for carbon emissions, the less volatile the stock price will be. More information that discloses information related to environmental or social disclosures will reduce information asymmetry so that the volatility of stock prices will be smaller and the disclosure has a negative effect on the volatility of stock prices. Likewise, Jayasree (2013) and Liu et al. (2013) found the same results, social and environmental responsibility disclosure can play the same role as financial disclosure in 
reducing information asymmetry in companies registered in China. Meanwhile, De Klerk et al. (2015) and Hapsoro et al. (2017) found a significant positive result. Whereas there are still different results, the authors conducted another study on the effect of disclosing carbon emissions on share price volatility. From the above studies, the hypothesis can be formulated, namely:

H7: Disclosure of company carbon emissions has a negative effect on the volatility of stock prices

\section{Theoritical Framework}

Based on the previous description, a research model can be prepared that describes the relationship between variables as follows:

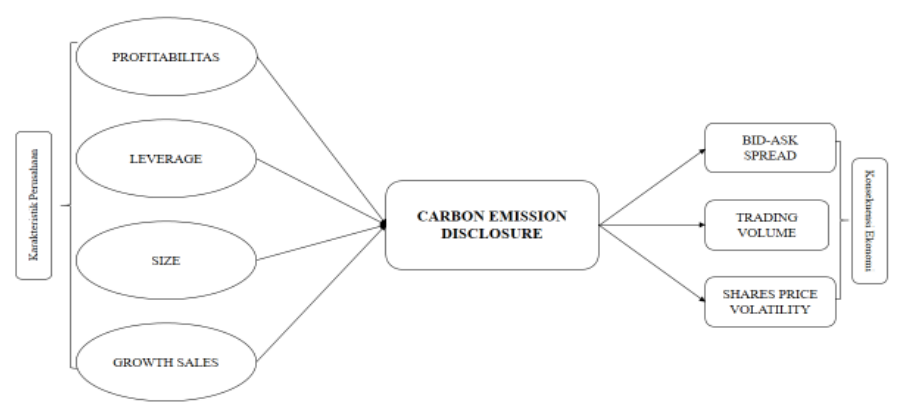

Figure 1. Research Model

\section{RESEARCH METHOD}

\section{Population and Sample}

The population used as research objects are non-financial companies engaged in the manufacturing, mining, oil, and gas industries listed in Indonesia, Malaysia, Thailand, Vietnam, and Philippines Stock Exchanges during the 2008-2017 period. A sample of 45 companies with a total of 450 observations. The sample selection used a purposive sampling technique based on Bloomberg data, annual reports, and sustainability reports.

\begin{tabular}{|c|l|c|c|c|c|}
\hline No & Criteria & \multicolumn{3}{|c|}{ Non-Financial Company } \\
\cline { 3 - 5 } & & Indonesia & Malaysia & Thailand & Filipina \\
\hline 1 & $\begin{array}{l}\text { Non-Financial Companies listed on the } \\
\text { Indonesia, Malaysia, Thailand and the } \\
\text { Philippines Stock Exchanges }\end{array}$ & 207 & 287 & 301 & 112 \\
\hline 2 & $\begin{array}{l}\text { Publish annual/financial reports as well } \\
\text { as environmental/SR reports for the }\end{array}$ & 14 & 10 & 13 & 8 \\
\hline
\end{tabular}




\begin{tabular}{|c|l|l|l|l|l|}
\hline & $\begin{array}{l}\text { period 2008-2017 and publish carbon } \\
\text { emission information (Bloomberg) }\end{array}$ & & & \\
\hline 3 & Total companies sampled & \multicolumn{3}{|c|}{$\mathbf{4 5}$ companies } \\
\hline
\end{tabular}

\section{Operationalization of Research Variables}

\section{Disclosure of carbon emissions}

The measurement method is to develop a checklist based on the CDP's information sheet

(Choi et al., 2013). The maximum score of all items is 18 and the minimum score is 0.

Each item has a value of 1 if the company makes a disclosure.

\section{Profitability}

Profitability is expressed in the form of a ratio, namely ROA, namely Total Profit / Total Assets.

\section{Leverage}

Leverage is expressed in the form of a ratio, namely Debt Ratio, namely Total Debt / Total Assets.

Size

Firm size is measured by the logarithm of Total Assets.

\section{Growth sales}

Sales growth is measured by the ratio of sales from year to year, namely by calculating the net sales in the current year minus the previous year's net sales and divided by the previous year's net sales.

\section{Bid-Ask Spread}

Spreadsi, $t=\{($ bidi, $\mathrm{t}-$ aski,t $) /($ bidi, $\mathrm{t}+$ aski,t $) / 2\} \times 100 / \mathrm{n}$

Spreadsi, $\mathrm{t}=$ The average difference between the highest buying price and the lowest selling price based on daily prices for one year

Ask = The lowest selling price or the asking price

Bid = The highest purchase price or bid price

$\mathrm{n}=$ Number of trading days for a year

\section{Trading Volume}

$$
\text { Trading Volume }=\sum_{t=1} \sum \text { VPSi,t }
$$


$\mathrm{n}$

VPSi $=$ Average daily trading volume of the company's shares in one year

VPSi, $\mathrm{t}=$ Daily stock trading volume of the company from the beginning of the year to the end of the year

$\mathrm{n}=$ Number of trading days for a year

\section{Shares Price Volatility}

$$
S^{2}=\frac{\sum_{i=1}^{n}\left(X_{i}-\bar{X}\right)^{2}}{n-1}
$$

$\mathrm{S} 2$ = Variant

$\mathrm{Xi}=$ The daily share price of the company in one year

$\mathrm{X}=$ Daily average share price

$\mathrm{n}=$ Number of trading days for a year

\section{Analysis Method}

The method of analysis in this research is by using PLS SEM. Processed with PLS 5.0 Warp software.

\section{RESULT AND DISCUSSION}

\section{Descriptive Statistic}

\begin{tabular}{|c|c|c|c|c|c|c|}
\hline \multirow[b]{2}{*}{ Variable } & \multicolumn{2}{|c|}{ Descriptive statistic } & \multirow[b]{2}{*}{ Minimum } & \multirow[b]{2}{*}{ Maximum } & \multirow[b]{2}{*}{$\begin{array}{l}\text { Standard } \\
\text { Deviation }\end{array}$} & \multirow[b]{2}{*}{$\begin{array}{l}\text { Coefficient } \\
\text { of Variance }\end{array}$} \\
\hline & Mean & Median & & & & \\
\hline Profit (\%) & 10.1026 & 7.5281 & -48.146 & 73.0662 & 11.7662 & 116.468 \\
\hline Leverage $(\%)$ & 27.6672 & 27.4584 & 0.14424 & 144.7120 & 19.7256 & 71.2958 \\
\hline Size & 5303.70 & 2433.48 & 129.002 & 68534.76 & 8621.471 & 162.556 \\
\hline Growth (\%) & 8.13943 & 5.74418 & -98.254 & 171.271 & 25.317 & 310.422 \\
\hline Bid-ask (\%) & -0.00087 & -0.00058 & -0.0451 & 0.00019 & 0.0027 & -311.208 \\
\hline $\mathrm{TV}(\mathrm{Jt})$ & 17.9469 & 5.26005 & 0.014953 & 611.7599 & 46.297 & 257.965 \\
\hline SPV & 0.32183 & 0.00730 & $2.87 \mathrm{E}-06$ & 21.6766 & 1.66651 & 527.981 \\
\hline CED (item) & 7.80222 & 8 & 0 & 17 & 5.5554 & 71.2032 \\
\hline
\end{tabular}

\section{PLS Analysis}

\begin{tabular}{llll}
\hline Indicator & Result & Criteria & Information \\
\hline
\end{tabular}




\begin{tabular}{|c|c|c|c|}
\hline & 0.260 & \multirow[b]{2}{*}{$<0.05$} & \multirow[b]{2}{*}{ Accepted } \\
\hline APC & $\begin{array}{r}(0.015) \\
0.154\end{array}$ & & \\
\hline ARS & $\begin{array}{r}(0.069) \\
0.122\end{array}$ & $<0.05$ & - \\
\hline AARS & $(0.099)$ & $<0.05$ & - \\
\hline AVIF & 1.130 & $3.3 \geq \mathrm{AVIF} \leq 5.5$ & Accepted \\
\hline AFVIF & 2.161 & $3.3 \geq \mathrm{AFVIF} \leq 5.5$ & Accepted \\
\hline GOF & 0.325 & $0,1 \leq \mathrm{GOF} \geq 0,36$ & Medium Fit \\
\hline SPR & 1 & $\begin{array}{cc}\mathrm{SPR}=1 & \text { or } \\
\mathrm{SPR} \geq 0,7 & \\
\mathrm{RSCR}=1 & \text { or }\end{array}$ & Accepted \\
\hline RSCR & 1 & $\mathrm{RSCR} \geq 0,7$ & Accepted \\
\hline SSR & 1 & $\mathrm{SSR} \geq 0,7$ & Accepted \\
\hline NLBCDR & 0,929 & $\mathrm{NLBCDR} \geq 0,7$ & Accepted \\
\hline
\end{tabular}

Based on the table above, the main model validation is by looking at the test results of the APC value is 0.260 ( $\mathrm{P}$-value $0.015<0.05)$, ARS is 0.154 ( $\mathrm{P}$-value $0.069>0.05)$, AARS is 0.122 (P-value 0.099>0.05). Likewise, AFVIF and AVFIF $\leq 3.3$ (multicollinearity test) and the resulting GOF value are 0.325 , which is included in the medium fit category. Then for Simpson's SPR paradox, the RSCR R-squared contribution ratio and SSR Statistical suppression ratio is 1 which means there is no causality problem in the model. Furthermore, the NLBCDR is worth $\geq 0.7$. These criteria have met the criteria for a fairly good Goodness of Fit Model.

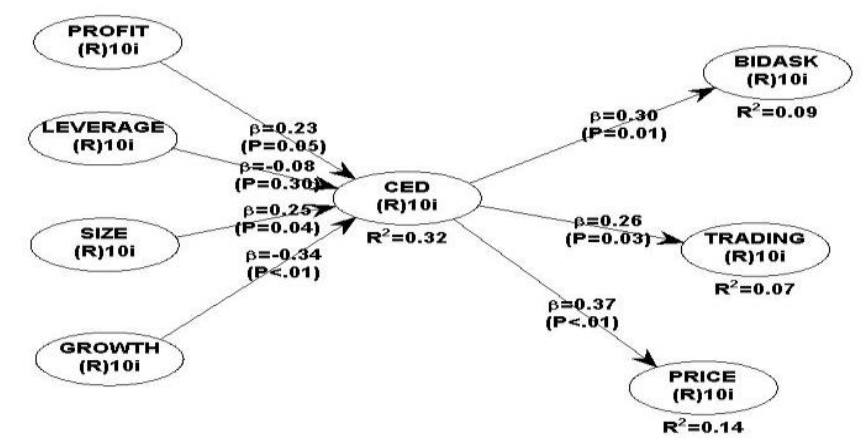

\begin{tabular}{ccccc}
\hline Variable & Hypothesis & $\begin{array}{c}\text { Coefficient } \\
\text { Path }\end{array}$ & $\begin{array}{c}\text { P- } \\
\text { value }\end{array}$ & Information \\
\hline $\begin{array}{c}\text { Profit } \\
\text { CED }\end{array}$ & + & 0,231 & 0,048 & Influence \\
\hline
\end{tabular}




\begin{tabular}{|c|c|c|c|c|c|}
\hline Lev & $\rightarrow$ & + & $-0,076$ & 0,302 & Not Influence \\
\hline CED & & & & & \\
\hline Size & $\longrightarrow$ & + & 0,246 & 0,037 & Influence \\
\hline CED & & & & & \\
\hline $\begin{array}{l}\text { Growth } \\
\text { CED }\end{array}$ & $\longrightarrow$ & + & $-0,336$ & 0,007 & Influence \\
\hline $\begin{array}{r}\text { CED } \\
\text { Bid Ask }\end{array}$ & $\rightarrow$ & - & 0,298 & 0,014 & Influence \\
\hline CED & $\rightarrow$ & + & 0,260 & 0,030 & Influence \\
\hline $\begin{array}{l}\text { Trade } \\
\text { CED } \\
\text { Price Vol }\end{array}$ & $\rightarrow$ & - & 0,371 & 0,003 & Influence \\
\hline
\end{tabular}

\section{Hypothesis Discussion}

\section{Profitability has a positive effect on disclosure of carbon emissions}

Based on the test results, the significance level is 0.048 , which is below five (5) percent and the coefficient of the profit variable is positive $(+)$ of 0.231 . This shows that profitability has a positive effect on the disclosure of carbon emissions, so hypothesis $\mathrm{H} 1$ is accepted. With a higher profit value, the company has the availability of funds for disclosing carbon emissions to the public. This disclosure of the information is expected to increase public trust so that it will have an impact on company profits in the future. These results support Choi et al. (2013), Suhardjanto, Setiany, Purwanto and Ashardianti (2018), Iatridis (2013), Ambarwati et al. (2017) and Jannah et al. (2014).

\section{Leverage has a positive effect on disclosure of carbon emissions}

Based on the test results, the significance level is 0.302, which is above five (5) percent and the coefficient of the leverage variable is negative (-) of 0.076 . This shows that leverage does not affect the disclosure of carbon emissions, so hypothesis $\mathrm{H} 2$ is rejected. This occurs because when stakeholder pressure on environmental and CSR disclosure increases, companies that face a high level of competitiveness is more sensitive to social pressure and consequently can provide more disclosure of CSR and better CSR strategies (Arafat, Warokka, Abdullah, \& Septian, 2012). However, because the research results show that leverage does not affect disclosure of carbon emissions, it can be said that stakeholders do not want to invest in companies with poor financial performance, are less sensitive to the environment, and tend to be reluctant to invest in companies with high risk or high leverage. This is consistent with what Epic (2015) states that low-income 
levels, high repair costs, political factors that undermine efficient policymaking, and market failures explain the prevalence of pollution in developing countries. The types of market failure that are often seen, namely weak property rights and poor access to credit, also distort the costs of improving environmental quality, so they cannot make promising investments in ecological quality that will pay off in the future.

\section{Company size has a positive effect on disclosure of carbon emissions}

Based on the test results, the significance level is 0.037, which is below five (5) percent and the coefficient of the firm size variable is positive $(+)$ of 0.246 . This shows that company size positively affects the disclosure of carbon emissions, so hypothesis $\mathrm{H} 3$ is accepted. The result of the path coefficient, which is positive, supports the legitimacy theory. In legitimacy theory, large companies will have greater pressure from environmental problems so that they tend to increase their response to the environment. This is because large companies tend to carry out more production processes that produce industrial pollution, which provides a positive relationship with the disclosure of carbon emissions that are still done voluntarily and even tend to enter this information in accounting reports without having to be asked. Apart from being in accordance with the principles of legitimacy theory, it is also in accordance with the stakeholder theory, which is that any activity carried out by the company has the right to know because the company will be subject to pressure besides the community as well as its stakeholders such as by making environmental-related disclosures that can be used to attract funding and as a preference for the business move. These results support Welbeck et al. (2017); Burgwal et al. (2014); Wang et al. (2013); Choi et al. (2013); Zhang et al. (2012); Jannah et al. (2014); Suhardi et al. (2015) and Ghomi et al. (2013).

\section{The company's sales growth has a positive effect on carbon emission disclosure}

Based on the test results, the significance level is 0.007. It is below five (5) percent and the coefficient of the sales growth variable is negative (-) of 0.336 . This shows that sales growth has a negative effect on the disclosure of carbon emissions, so hypothesis $\mathrm{H} 4$ is rejected. This significant negative result is in accordance with Widiastuti, Utami, and Handoko (2018) which state that high growth companies indicate that the company focuses on operating activities and reduces non-operational activities, namely social and environmental related activities. High growth companies are more focused on financial 
performance to meet the interests of the main stakeholders, namely investors and slightly ignore other stakeholders' interests, namely the community. Evandini et al. (2014), Luo et al. (2013), Effendi et al. (2015) and Waluyo., (2017).

\section{The company's carbon emission disclosure has a negative effect on the bid-ask spread}

Based on the test results, the significance level is 0.014, under five (5) percent and the coefficient of the bid-ask spread variable is positive (+) of 0.336 . This shows that the disclosure of carbon emissions positively affects the bid-ask spread so that hypothesis H5 is rejected. For this reason, in this study, it can be said that the disclosure of carbon emissions has not been fully known by most investors, so that it is asymmetric in the information. In addition, this disclosure is not a top priority. Investors will be more interested in seeing the company's financial performance, considering that the resulting spread will be more comprehensive. This is because investors with inadequate information will suffer losses because they are unable to make the best estimate of the company's performance. This results in a significant difference between the company's bid value and the asking value desired by investors (Kim \& Verrecchia, 1991; Brandenburg, 2013; Glosten \& Milgrom, 1985). These results are in accordance with Candra and Juniarti (2017) and Hapsoro and Fadhilla (2017).

\section{The company's carbon emission disclosure has a positive effect on trading volume}

Based on the test results, the significance level is 0.03 , which is below five (5) percent and the coefficient of the trading volume variable is positive (+) of 0.260 . This shows that the disclosure of carbon emissions has a positive effect on trading volume, so hypothesis H6 is accepted.

The high volume of stock trading indicates that investors have a great interest in the company's shares. In addition, the influence of information is also tremendous, especially information that is good news because it will increase the volume and volatility of stock returns (Tapa \& Hussin, 2016). This result is in accordance with Hapsoro et al. (2017), Zidni (2016), Hapsoro et al. (2015), and Ambarwati et al. (2017)

\section{The company's carbon emission disclosure has a negative effect on share price volatility}

Based on the test results, the significance level is 0.003 , which is below five (5) percent and the coefficient of the variable share price volatility is positive (+) of 0.371 . This shows 
that the disclosure of carbon emissions has a positive effect on share price volatility, so hypothesis H7 is rejected. According to Hapsoro et al. (2017), positive results stated that disclosure of carbon emissions listed in annual reports and sustainability reports is only a mutual concern of investors only as a consideration for their investment decisions. Likewise with De Klerk et al. (2015).

\section{CONCLUSION}

\section{Conclusion}

Based on the findings obtained in research on the effect of company characteristics on disclosure of carbon emissions and their impact on economic consequences on nonfinancial companies listed in Indonesia, Malaysia, Thailand, and the Philippines, it can be concluded that the variable company characteristics, including profitability and size, has a positive effect while sales growth (growth companies) have a negative impact on disclosure of carbon emissions and leverage has no effect on disclosure of carbon emissions. The disclosure of carbon emissions positively affects economic consequence variables, including the Bid-Ask Spread, trading volume, and stock price volatility.

\section{Suggestion}

The suggestions that can be given are:

a. A study was conducted by comparing each industry in each country that produces carbon emissions to be more varied. In addition, it can also use other carbon emission disclosure standards such as the inclusion of carbon emissions in the Sustainable Report, GRI and ISO, Proper and others.

b. Using different research methods to get more mixed results.

c. Use other variables related to the breadth of information or use variables associated with the political and economic conditions of a country.

d. This research was conducted in mining and manufacturing companies in the future, and it can be carried out in other types of industries

e. In calculating the economic consequence variable, the annual average is calculated using the lagged $1(\mathrm{t}-1)$ formula or the average data of the previous 1 year to calculate the economic consequence variable in the current year.

\section{Implications}




\section{Implications Theory}

1) Claims that state that about legitimacy (Donaldson \& Preston (1995)); (Patten, 1992; Deegan \& Rankin, 1997). This theory is still relevant, especially for companies with a good level of profitability, so it will be easier to create and report on their environmental performance. In addition, this theory also applies to companies with large sizes. Companies that have a large size will get more attention and pressure from the public. For this reason, they will report their environmental performance to legitimize the public to believe that companies with large profitability and size will care more about the environment.

2) The signal theory assumes that managers have a lot of information that can be used to predict future company performance, so company managers are able to predict future performance because they have more information than outsiders. Managers are able to improve company performance through voluntary disclosure and are considered relevant for image building (Healy \& Palepu, 2001). This theory is still relevant because disclosure of carbon emissions provides an excellent signal to investor interest. This occurs in the increasing volume of stock trading on the stock market.

3) Stakeholder theory that company management is expected to carry out activities mandated by stakeholders and report on these activities. Stakeholders have the right to receive information about the impact that will be caused by the activities carried out by the company. (Guthrie et al., 2004). This theory still applies that large companies will make disclosures by paying attention to all aspects. And the manager will notify the company's financial conditions to be known by stakeholders. Just as a company discloses carbon emissions, stakeholders need to know the pros and cons for the company. This carbon disclosure can also be a basis for looking at future business opportunities.

\section{Managerial Implications}

1) Measures of company characteristics related and relevant to company performance, namely Profitability and Size. Leverage and growth are not suitable company characteristics measures to determine a company's performance in disclosing its carbon emissions.

2) Disclosure of carbon emissions greatly affects the volume of stock trading. So this is a concern for companies in including these disclosures in their company reports. 


\section{Investor Implications}

It would be wise to invest in considering the absence of reports related to carbon emissions and carbon reduction or removal by companies. The development of the world will focus more on climate management in investing.

\section{References}

Abubakar, A. A. (2017). Impact of Environmental Disclosure on Performance of Cement and Brewery Companies in Nigeria. Research Journal Of Finance And Accounting, $8(21), 31-35$.

Akrout, M. M., \& Ben Othman, H. (2015). Environmental Disclosure and Stock Market Liquidity: Evidence from Arab MENA Emerging Markets. Applied Economics, 48(20), 1840-1851.

Ambarwati, \& Hapsoro, D. (2017). Antecedents and Consequences of Carbon Emission Disclosure. Proceeding: The 5th Gadjah Mada International Conference on Economics and Business.

Arafat, M. Y., Warokka, A., Abdullah, H. H., \& Septian, R. R. (2012). The Triple Bottom Line Effect on Emerging Market Companies: A Test of The Triple Bottom Line Effect on Emerging Market Companies : A Test of Corporate Social Responsibility and Firm Value Relationship. IBIMA Publishing, 2012 (September 2014).

Astuti, C. W., \& Nugrahanti, Y. W. (2015). Pengaruh Pengungkapan Corporate Social Responsibility terhadap Reaksi Pasar. Dinamika Akuntansi, Keuangan Dan Perbankan, 4(2), 90-105.

Blanco, C., Caro, F., \& Corbett, C. J. (2017). An Inside Perspective on Carbon Disclosure. Business Horizons, 60(5), 635-646.

Burgwal, D. Van De, \& Vieira, R. (2014). Environmental Disclosure Determinants in Dutch Listed Companies. Revista Contabilidade \& Finanças, 25(64), 60-78.

Candra, A. A., \& Juniarti. (2017). Pengaruh Tingkat Pengungkapan Corporate Social Responsibility Terhadap Information Asymmetry Dengan Variabel Kontrol Dividend Yield Dan Market-To-Book Ratio Pada Perusahaan Terbuka Di Indonesia. Akuntansi Bisnis Universitas Kristen Petra, 85-97.

Chauhan, S., \& Amit. (2014). A Relational Study of Firm's Characteristics and CSR Expenditure. Procedia Economics and Finance, 11(14), 23-32. 
Chithambo, L., \& Tauringana, V. (2014). Company Specific Determinants of Greenhouse Gases Disclosures. Journal of Applied Accounting Research, 15(3), 323-338.

Cho, S. Y., Lee, C., \& Pfeiffer, R. J. (2013). Corporate social responsibility performance and information asymmetry. Journal of Accounting and Public Policy, 32(1), 71-83.

Choi, B. B., Lee, D., \& Psaros, J. (2013). An Analysis of Australian Company Carbon Emission Disclosures. Pacific Accounting Review, 25(1), 58-79.

Cotter, J., \& Najah, M. M. (2011). Institutional Investor Influence on Global Climate Change Disclosure Practices. Australian Journal of Management.

De Klerk, M., De Villiers, C., \& Van Staden, C. (2015). The Influence of Corporate Social Responsibility Disclosure on Share Prices: Evidence from The United Kingdom. Pacific Accounting Review, 27(2), 208-228.

Deegan, C., \& Rankin, M. (1997). The Materiality of Environmental Information to Users of Annual Reports (Vol. 10).

Donaldson, T., \& Preston, L. E. (1995). the Stakeholder Theory of the Corporation: Concepts, Evidence, and Implications. Academy of Management Review, 20(1), 6591.

Effendi, F. R. M., \& Hapsari, D. W. (2015). Analisis Pengaruh Profitabilitas, Ukuran Perusahaan, dan Pertumbuhan Perusahaan terhadap Pengungkapan Tanggungjawab Sosial Perusahaan. E-Proceeding of Management, 2(3), 3409-3416.

Evandini, C., \& Darsono. (2014). Faktor-Faktor Yang Berpengaruh Terhadap Penerimaan. Diponegoro Journal of Accounting, 3(3), 1-11.

Ghomi, Z. B., \& Leung, P. (2013). An Empirical Analysis of the Determinants of Greenhouse Gas Voluntary Disclosure in Australia. Accounting and Finance Research, 2(1), 110-127.

Gray, R., Kouhy, R., \& Lavers, S. (1995). Corporate Social and Environmental Reporting. Accounting, Auditing \& Accountability Journal, 8(2), 47-77.

Guthrie, J., Petty, R., Yongvanich, K., \& Ricceri, F. (2004). Using Content Analysis as a Research Method to Iquire into Intellectual Capital Reporting. Journal of Intellectual Capital, 5(2), 282-293.

Haigh, M., \& Shapiro, M. A. (2011). Carbon reporting: Does it matter? Accounting, Auditing and Accountability Journal, 25(1), 105-125. 
Hapsoro, D., \& Fadhilla, A. F. (2017). Relationship Analysis of Corporate Governance, Corporate Social Responsibility Disclosure and Economic Consequences: Empirical Study of Indonesia Capital Market. The South East Asian Journal of Management, 11(2), 164-182.

Hapsoro, D., \& Zidni, M. H. (2015). The Effect of Corporate Social Responsibility Disclosure on Economic Consequences: Case Study in Indonesia. Journal of Business and Economics, 6(9), 1595-1605.

Healy, P. M., \& Palepu, K. G. (2001). Information Asymmetry Corporate Disclosure and the Capital Markets: A Reviw of The Empirical Disclosure Literature. Journal of Accounting and Economics, 31, 405-440.

Iatridis, G. E. (2013). Environmental Disclosure Quality: Evidence on Environmental Performance, Corporate Governance and Value Relevance. Emerging Markets Review, 14(1), 55-75.

Irwhantoko, I., \& Basuki, B. (2016). Carbon Emission Disclosure: Studi pada Perusahaan Manufaktur Indonesia. Jurnal Akuntansi Dan Keuangan, 18(2), 92-104.

Jannah, R., \& Muid, D. (2014). Analisis Faktor-Faktor yang Mempengaruhi Carbon Emission Disclosure pada Perusahaan di Indonesia (Studi Empiris pada Perusahaan yang Terdaftar di Bursa Efek Indonesia Periode 2010-2012). Diponegoro Journal of Accounting, 3(2), 2337-3806.

Jayasree, M. (2013). Disclosures and Stock Price Volatility: A Study of Indian Stock Market. The International Journal of Management, 1(3), 1-11.

Kansal, M., Joshi, M., \& Batra, G. S. (2014). Determinants of corporate social responsibility disclosures: Evidence from India. Advances in Accounting, 30(1), 217-229.

Knudsen, S. (2016). Is Corporate Social Responsibility Oiling the Neoliberal Carbon Economy? Ethnos.

Kusumah, R. W. R., Manurung, D. T. H., Oktari, S. D., \& Husnatarina, F. (2016). Analysis of Factors Affecting Carbon Emission Disclosure (An Empirical Study at Companies registered with Sustainability Reporting 2015) Analysis of Factors Affecting Carbon Emission Disclosure (An Empirical Study at Companies Registered with Sustainabili. 8th Widyatama International Seminar on 
Sustainability Analysis, (October).

Latan, Hengky \& Ghozali, Imam. (2017). Partial Least Squares Konsep, Metode dan Aplikasi Menggunakan Program Warp PLS 5.0, Third Edition, Semarang: Badan Penerbit Universitas Diponegoro.

Leuz, C., \& Verrecchia, R. E. (2000). Economic Consequences of Increase Disclosure. Journal of Accounting Research, 38, 91-124.

Lucyanda, J., \& Siagian, L. G. (2012). The Influence of Company Characteristics Toward Corporate Social Responsibility Disclosure. The 2012 International Conference on Business and Management, (Viii), 601-619.

Luo, L., Tang, Q., \& Lan, Y.-C. (2013). Comparison of Propensity for Carbon Disclosure between Developing and Developed Countries: A Resource Constraint Perspective. Accounting Research Journal, 26(1), 6-34.

Michaels, A., \& Gruning, M. (2017). Relationship of Corporate Social Responsibility Disclosure on Information Asymmetry and The Cost of Capital. Journal of Management Control, 28(3), 251-274.

Munsaidah, S., Andini, R., \& Supriyanto, A. (2016). Analisis Pengaruh Firm Size, Age, Profitabilitas, Leverage, dan Growth Perusahaan terhadap Corporate Social Rerponsibility (CSR) pada Perusahaan Property dan Real Estate yang Terdaftar di Bursa Efek Indonesia Pada Tahun 2010-2014. Journal of Accounting, 2(2).

Patten, D. M. (1992). THE address the social issues inherently related to the organizations . Unlike economic performance which could be quantitatively measured via profits, social performance was outside the realm of the market system . Accordingly, social concerns were add. Accounting, Organizations and Society, 17(5), 471-475.

Prafitri, A., \& Zulaikha. (2016). Analisis Pengungkapan Emisi Gas Rumah Kaca. Jurnal Akuntansi Dan Auditing, 13(2), 155-175.

Ratmono, Dwi \& Sholihin, Mahfud. (2013). Analisis SEM-PLS dengan WARp PLS 3.0 untuk Hubungan Nonlinier dalam Penelitian Sosial dan Bisnis, Jogjakarta: Penerbit ANDI.

Saka, C., \& Oshika, T. (2014). Disclosure Effects, Carbon Emissions and Corporate Value. Sustainability Accounting, Management and Policy Journal, 5(1), 22-45. 
Suhardjanto, D., Setiany, E., Purwanto, \& Ashardianti, D. (2018). Environmental Disclosure in Agricultural Sector and Consumer Goods Annual Report ( Comparison between Indonesia and Malaysia ). Review of Integrative Business and Economics Research, 7(4), 203-215.

Tapa, A., \& Hussin, M. (2016). The Relationship between Stock Return and Trading Volume in Malaysian ACE Market. International Journal of Economics and Financial Issues, 6, 271-278.

Waluyo, W. (2017). Firm Size, Firm Age, and Firm Growth on Corporate Social Responsibility in Indonesia: The Case of Real Estate Companies. European Research Studies Journal, 20(4), 360-369.

Wang, J., Song, L., \& Yao, S. (2013). The Determinants of Corporate Social Responsibility Disclosure: Evidence from China. Journal of Applied Business Research, 29(6), 1833-1847.

Welbeck, E. E., Owusu, G. M. Y., Bekoe, R. A., \& Kusi, J. A. (2017). Determinants of Environmental Disclosures of Listed Firms in Ghana. International Journal of Corporate Social Responsibility, 2(1), 11.

Widiastuti, H., Utami, E. R., \& Handoko, R. (2018). Pengaruh Ukuran Perusahaan , Tipe Industri , Growth , dan Media Perusahaan ( Studi Empiris pada Perusahaan yang Terdaftar di Bursa Efek Indonesia Tahun 2014-2015. Riset Akuntansi Dan Keuangan Indonesia, 3(2), 107-117.

Wulandari, P. P., \& Atmini, S. (2012). Pengaruh Tingkat Pengungkapan Wajib dan Pengungkapan Sukarela Terhadap Biaya Modal Ekuitas. Jurnal Akuntansi Multiparadigma, 3, 424-440.

Zhang, S., Mcnicholas, P., \& Birt, J. (2012). Australian Corporate Responses to Climate Change: The Carbon Disclosure Project Paper to be presented at the RMIT Accounting for Sustainability Conference on the 28 th of May 2012 by Australian Corporate Responses to Climate Change: The Carbon Disclosur. Paper Presented at the RMIT Accounting for Sustainability Conference in May 2012, (May).

Zidni, M. H. (2016). Pengaruh Pengungkapan Corporate Social Responsibility Terhadap Konsekuensi Ekonomi. Jurnal Akuntansi Dan Manajemen, 27(1), 11-26 